\title{
Managerial Perceptions on Internal Business Process Perspective in Commercial Banks of Nepal
}

Dilip Prarajuli, PhD

Associate Professor, Tribhuvan University

Email: dilipparajuli@hotmail.com

\begin{abstract}
This paper aims to explore managerial perceptions on the internal business process perspective in Nepalese commercial banks. A set of questionnaire consisting five-point Likert-type scale statements was administered to collect data from sample units; stateowned banks, private banks, and joint venture banks. The findings indicate that customer need satisfaction has been perceived as the top priority measure of the internal business process perspective in Nepalese banks. Distribution reach and process delivery aspects of the internal process perspective have also got more preferences as per the perceptions of the managers. However, some other aspects such as service cycle duration, a sufficient number of training hours, and a comprehensive innovation process seem to be less preferred. The overall results show that the internal business process as per the response is satisfactory.
\end{abstract}

Keywords: managerial perception, balanced scorecard, internal business process, perspective

\section{Introduction}

The internal business process perspective is one of the key dimensions of the Balanced Scorecard (BSC) approach measuring corporate performance which examines the strength of organizations in operating their business activities (Parajuli, 2017). Over the last 20 years, the Balanced Scorecard (BSC), first created by Kaplan and Norton in 1992, has been developed, attracting attention all over the world (Hasan \& Chyi, 2017). The $\mathrm{BSC}$ approach is an integrated set of financial and non-financial measures used in the implementation process of the strategy of a business that underlines the communication strategy with the stakeholders and provides input on the organization's objectives (Mendoza \& Zrihen, 2001). It can be used for the total organization or a sub-unit at different levels or as a "personal scorecard." The scorecard can be useful either in the sub-unit or as a personal scorecard at different levels of the organization. The BSC approach will provide executives with the resources they need to succeed in the future and the ability of executives to track the success of the plan of a company. This approach enables a company to take its mission and strategy and then convert them into a series of 
success metrics that provide the basis for a strategic management framework. The BSC approach contains conventional financial goals, but also includes goals that drive financial results (Alshammari, 2011).

From a management strategy point of view, the aim of the BSC approach is to bring the company objectives, mission, and vision into perspective through key performance indicators and decision making. Kaplan and Norton (2001) reported the four major broad categories of this approach like learning and growth, internal business processes, consumer, and financial perspective. Each perspective of the BSC model defines strategic objectives that can give a competitive advantage to the company (Szóka, 2012). One of the core aspects of the BSC approach is the internal business process perspective. The internal business process perspective of the BSC approach represents the use of available resources, processes, and techniques in carrying business operations. Therefore, this paper aims to explore managerial perceptions on this perspective by considering three bank categories of Nepal.

\section{Review of Literature}

The BSC approach is a multi-dimensional scorecard for corporate performance. Recently, Hegazy, Hegazy, and Eldeeb (2020) reported that this approach provides a framework for the selection of several main performance measures that complement conventional financial measures with customer satisfaction operating measures, internal business processes, and activities for learning and growth (Kaplan \& Norton, 1992). It is a move to link the 'short-term operational controls' to the company's 'long-term vision and strategy.' Strategy and vision are the priority. It forces the company to match its performance assessment and controls with the internal business processes and experiences of learning and growth and analyze their effect on the financial indicators (Anand, Sahay, \& Saha, 2005). It also considers customer perspectives. However, this paper concerns with the internal business process aspect of the BSC approach.

Many literature sources explained the internal business process as one of the key perspectives of the BSC approach. Alshammari (2011) stated that metrics based on this perspective enable managers to determine how well their organization performs and if goods and services comply with consumer requirements (the mission). These measures must be carefully crafted by those who are most closely aware of these processes; they should not be produced solely by outside experts with the particular missions of companies. Sharma (2003) argued that BSC indicators for the internal business process perspective often quoted include the process of innovation, the process of operations, and post-sales support. Parajuli (2017) reported that to generate consumer delight, this perspective allows the organization to evaluate its competencies and the processes where 
it must succeed. The main goals are process development and partnerships with suppliers. Cycle time, quality efficiency, productivity, and after-sales support are mechanisms for evaluating measures. Waluyo et al. (2015) also reported some measures of the internal business process of the BSC approach like innovation process, operational process, after-sale service process, ease of payment process, satisfying market segment through product or service, a high-level taste of art worker, fast response on art technology. However, based on different literature sources, this paper applied 10 items such as service cycle duration, distribution reach, new product/ service, number of training hours, identification of customer needs, comprehensive innovation process, operation process, post-sales service, satisfy customer needs, and process delivery as the key measures to present the managerial perceptions on the internal business perspective of commercial banks of Nepal.

\section{Research Methodology}

This is an exploratory type of paper. It is concerned to explore managerial perceptions of the internal business process perspective of the BSC approach. The questionnaire survey is a simple research instrument used for the study to collect data. Three groups of banks, such as state-owned banks, private banks, and joint venture banks are the study units of this paper. A five-point Likert-type scale from strongly disagree (1) to strongly agree (5) was used to explore managerial perceptions.

A total of 1,015 questionnaires were distributed among the managers of these banks' various branches. Table 1 lists the specifics of the distributed questionnaire and its response rate.

Table 1

Responses from Three Bank Groups

\begin{tabular}{llll}
\hline Classes of Banks & $\begin{array}{l}\text { No. of questionnaires } \\
\text { distributed }\end{array}$ & $\begin{array}{l}\text { No. of Responses } \\
\text { received }\end{array}$ & $\begin{array}{l}\text { Response } \\
\text { rate (\%) }\end{array}$ \\
\hline State owned banks & 105 & 78 & 74.29 \\
Private banks & 735 & 278 & 37.82 \\
Joint venture banks & 175 & 110 & 62.86 \\
\hline Total & 1015 & 466 & 46 \\
\hline
\end{tabular}

\section{Results and Findings}

The following sections describe the items under the internal business process perspective as per responses of managers from three bank groups. 


\section{Service Cycle Duration}

The organizations which have less service cycle duration enjoy more operating efficiencies. The statement - we have less service cycle duration was - asked the respondents for rating. Table 2 summarizes the result received from the respondents.

Table 2

Service Cycle Duration

\begin{tabular}{lllllll}
\hline Type of the banks & $\begin{array}{l}\text { Strongly } \\
\text { Disagree }\end{array}$ & Disagree & Undecided & Agree & $\begin{array}{l}\text { Strongly } \\
\text { Agree }\end{array}$ & Total \\
\hline State owned banks & 2 & 15 & 21 & 37 & 3 & 78 \\
Private banks & 8 & 47 & 93 & 119 & 11 & 278 \\
Joint venture banks & 0 & 10 & 40 & 59 & 1 & 110 \\
\hline Total & 10 & 72 & 154 & 215 & 15 & 466 \\
\hline
\end{tabular}

Out of 466 respondents, 215 representing a majority of the respondents agreed that we have less service cycle duration of their banks. Similarly, 15 of them have shown their strong agreement with the statement. However, 154 respondents were undecided, 72 disagreed and 10 strongly disagreed to state their bank having less service cycle duration. The result shows that most of the respondents are confirmed about less service cycle duration of their banks.

\section{Distribution Reach}

An internally strong company gets success in maintaining a wide range of distribution reach. We have included this item to examine the distribution strength of the bank to distribute their product. The result of the survey has been presented in Table 3 .

Table 3

Distribution Reach

\begin{tabular}{lllllll}
\hline Type of the banks & $\begin{array}{l}\text { Strongly } \\
\text { Disagree }\end{array}$ & Disagree & Undecided & Agree & $\begin{array}{l}\text { Strongly } \\
\text { Agree }\end{array}$ & Total \\
\hline State owned banks & 1 & 1 & 9 & 31 & 36 & 78 \\
Private banks & 2 & 29 & 77 & 139 & 31 & 278 \\
Joint venture banks & 0 & 7 & 24 & 62 & 17 & 110 \\
\hline Total & 3 & 37 & 110 & 232 & 84 & 466 \\
\hline
\end{tabular}

The result from the survey indicates that most of the respondents have replied that our bank has a wide range of distribution reach. Among 466 respondents, 84 strongly agreed, 232 agreed with this statement. Similarly, 37 were found to have disagreed, 110 are undecided and three of them were strongly disagreed. 


\section{New Product/Service}

The companies having the capacity to developing new products and services frequently can have more comparative advantages and shows strong internal business condition.

Our respondents have produced the following opinion in Table 4.

Table 4

New Product/ Service Introduction

\begin{tabular}{lllllll}
\hline \multirow{2}{*}{ Type of the Banks } & $\begin{array}{l}\text { Strongly } \\
\text { Disagree }\end{array}$ & Disagree & Undecided & Agree & $\begin{array}{l}\text { Strongly } \\
\text { Agree }\end{array}$ & Total \\
\hline State owned banks & 2 & 15 & 24 & 33 & 4 & 78 \\
Private banks & 2 & 43 & 76 & 133 & 24 & 278 \\
Joint venture banks & 0 & 15 & 20 & 60 & 15 & 110 \\
\hline Total & 4 & 73 & 120 & 226 & 43 & 466 \\
\hline
\end{tabular}

Out of 466 total respondents, 43 have shown strong agreement and 226 agreed that their bank frequently introduces new products/ services. The result shows that most of the banks are adopting new pricing strategies to improve their financial conditions. However, 120 respondents remained undecided and 73 disagreed and only four respondents strongly disagreed. Similarly, joint venture banks frequently introduce new products/ services more than private banks and state owned banks.

\section{Number of Training Hours}

More training hours are required for the staff to execute the internal organizational responsibilities smoothly and efficiently. Table 5 indicates the significance of the sufficient number of training hours as responded by the manager.

Table 5

Number of Training Hours

\begin{tabular}{lllllll}
\hline \multirow{2}{*}{ Type of the Banks } & $\begin{array}{l}\text { Strongly } \\
\text { Disagree }\end{array}$ & Disagree & Undecided & Agree & $\begin{array}{l}\text { Strongly } \\
\text { Agree }\end{array}$ & Total \\
\hline State owned banks & 2 & 14 & 15 & 35 & 12 & 78 \\
Private banks & 15 & 53 & 75 & 118 & 17 & 278 \\
Joint venture banks & 2 & 12 & 37 & 48 & 11 & 110 \\
\hline Total & 19 & 79 & 127 & 201 & 40 & 466 \\
\hline
\end{tabular}

The result has shown that 201 out of 466 respondents have shown their agreement to the statement that our bank has a sufficient number of training hours. Similarly, 40 of them are found to have strongly agreed with this statement. However, 19 respondents strongly disagreed but 79 disagreed and 127 were undecided about the statement. The conclusion 
hence derived indicates that state owned banks reasonably provide a sufficient number of training hours compared to the trend of private banks and joint venture banks.

\section{Identification of Customer Needs}

Companies need to explore and identify customer needs frequently and respond to them as quickly as possible. To know the opinion of the managers about their practice regarding customer needs, the statement that our bank identifies customer needs frequently was put forward and Table 6 shows the result.

Table 6

Identification of Customer Needs

\begin{tabular}{lllllll}
\hline Type of the Banks & $\begin{array}{l}\text { Strongly } \\
\text { Disagree }\end{array}$ & Disagree & Undecided & Agree & $\begin{array}{l}\text { Strongly } \\
\text { Agree }\end{array}$ & Total \\
& 1 & 17 & 29 & 29 & 2 & 78 \\
\hline State owned banks & 4 & 47 & 77 & 133 & 17 & 278 \\
Private banks & 1 & 11 & 34 & 55 & 9 & 110 \\
Joint venture banks & 1 & 75 & 140 & 217 & 28 & 466 \\
\hline Total & 6 & &
\end{tabular}

Out of 466 respondents, 217 respondents agreed to the statement that their bank identifies customer needs frequently. Similarly, 28 of them have shown their strong agreement with the statement. However, 140 respondents were undecided, 75 disagreed and six were strongly disagreed with the statement. The result shows that most of the respondents are convinced that their bank identifies customer needs frequently.

\section{Comprehensive Innovation Process}

To meet customer needs it is necessary to follow a comprehensive innovation process. The responses of the manager in connection to it have been presented in Table 7.

Table 7

Comprehensive Innovation Process

\begin{tabular}{lllllll}
\hline Type of the Banks & $\begin{array}{l}\text { Strongly } \\
\text { Disagree }\end{array}$ & Disagree & Undecided & Agree & $\begin{array}{l}\text { Strongly } \\
\text { Agree }\end{array}$ & Total \\
\hline State owned banks & 5 & 12 & 32 & 27 & 2 & 78 \\
Private banks & 10 & 50 & 78 & 114 & 26 & 278 \\
Joint venture banks & 1 & 12 & 43 & 44 & 10 & 110 \\
\hline Total & 16 & 74 & 153 & 185 & 38 & 466 \\
\hline
\end{tabular}

The result from the survey indicates that most of the respondents have replied that their banks have been followed a comprehensive innovation process. Out of 466 respondents 
38 strongly agreed, 185 agreed with this statement. Similarly, 74 were found to have disagreed, 153 remained undecided and 16 strongly disagreed.

\section{Operation Process}

A strong company should have an internal strength of a smooth and systematic operating process. This statement was included in the survey to find the existing operating process of the banks. The result of the survey has been presented in Table 8 .

Table 8

Operation Process

\begin{tabular}{lllllll}
\hline Type of the Banks & $\begin{array}{l}\text { Strongly } \\
\text { Disagree }\end{array}$ & Disagree & Undecided & Agree & $\begin{array}{l}\text { Strongly } \\
\text { Agree }\end{array}$ & Total \\
\hline State owned banks & 3 & 10 & 12 & 51 & 2 & 78 \\
Private banks & 6 & 43 & 62 & 140 & 27 & 278 \\
Joint venture banks & 0 & 6 & 29 & 66 & 9 & 110 \\
\hline Total & 9 & 59 & 103 & 257 & 38 & 466 \\
\hline
\end{tabular}

Table 8 depicts that among the total of 466 respondents, 38 have shown strong agreement and 257 agreed that their bank has a smooth and systematic operation process. The result shows that most of the banks are adopting a smooth and systematic operation process to improve their internal process. However, 103 respondents were undecided and 59 disagreed and nine respondents strongly disagreed. Similarly, the joint venture banks have applied smooth and systematic operation process more than the private bank and state owned banks.

\section{Post Sales Service}

Providing enough after-sale service is another dimension of measuring performance in internal business. The current study has applied this item and the result of the survey has been presented in Table 9.

Table 9

Post sale Service

\begin{tabular}{lllllll}
\hline \multirow{2}{*}{ Type of the Banks } & $\begin{array}{l}\text { Strongly } \\
\text { Disagre }\end{array}$ & Disagree & Undecided & Agree & $\begin{array}{l}\text { Strongly } \\
\text { Agree }\end{array}$ & Total \\
\hline State owned banks & 1 & 12 & 29 & 34 & 2 & 78 \\
Private banks & 2 & 36 & 87 & 135 & 18 & 278 \\
Joint venture banks & 0 & 5 & 35 & 60 & 10 & 110 \\
\hline Total & 3 & 53 & 151 & 229 & 30 & 466 \\
\hline
\end{tabular}


The result has shown that 229 from 466 respondents have shown their agreement to the statement that their bank offers more post-sale service which shows the better internal business of the banks. Similarly, 30 of them are found to have strongly agreed with this statement. However, three respondents have strongly disagreed but 53 have disagreed and 151 were undecided about the statement. So, banks especially from the joint venture and private groups have offered more post-sale service than that of the state owned banks.

\section{Satisfy Customer Needs}

The match between customer needs and internal business process leads a company towards success. To know how far the commercial banks can satisfy their customer needs, the statement that their banks aim to satisfy customer needs was put forward for the rating, and Table 10 shows the result.

Table 10

Satisfy Customer Needs

\begin{tabular}{lllllll}
\hline Type of the Banks & $\begin{array}{l}\text { Strongly } \\
\text { Disagree }\end{array}$ & Disagree & Undecided & Agree & $\begin{array}{l}\text { Strongly } \\
\text { Agree }\end{array}$ & Total \\
\hline State owned banks & 0 & 2 & 14 & 43 & 19 & 78 \\
Private banks & 3 & 15 & 36 & 157 & 67 & 278 \\
Joint venture banks & 0 & 1 & 15 & 63 & 31 & 110 \\
\hline Total & 3 & 18 & 65 & 263 & 117 & 466 \\
\hline
\end{tabular}

Out of 466 respondents, 263 agreed to the statement that their bank aims to satisfy the customer. Similarly, 117 of them have shown their strong agreement with the statement. However, 65 respondents were undecided, 18 disagreed and three strongly disagreed with the statement. The result shows that most of the respondents are convinced that the banks aim to satisfy the customer.

\section{Process Delivery}

The ability to use better processes and service delivery also indicates company performance from the internal business perspective. Table 11 shows the responses from the managers' relation to process delivery of their banks. The result from the survey indicates that the majority of the respondents have replied that their banks have better process delivery. Out of 466 respondents, 49 were strongly agreed, and 271 agreed with this statement. Similarly, 39 were found to have disagreed, whereas 94 were undecided and 13 strongly disagreed. 
Table 11

Process Delivery

\begin{tabular}{lllllll}
\hline Type of the Banks & $\begin{array}{l}\text { Strongly } \\
\text { Disagree }\end{array}$ & Disagree & Undecided & Agree & $\begin{array}{l}\text { Strongly } \\
\text { Agree }\end{array}$ & Total \\
\hline State owned banks & 1 & 4 & 17 & 49 & 7 & 78 \\
Private banks & 12 & 28 & 60 & 148 & 30 & 278 \\
Joint venture banks & 0 & 7 & 17 & 74 & 12 & 110 \\
\hline Total & 13 & 39 & 94 & 271 & 49 & 466 \\
\hline
\end{tabular}

\section{Conclusion}

Kaplan and Norton (2004) argued that the strategic perspective of the internal business process was integrated into the BSC approach of the organization. Kaplan and Norton $(2005 ; 2006)$ reported that the BSC approach is used to define, communicate, and formulate strategies (Kaplan \& Norton, 2005; 2006). Olson and Slater 2002) also argued that the goal of the BSC approach is to align the organizational output with the strategy, and its scope is the execution of the strategy. The internal business process perspective represents the internal processes that should comply with the on-time accomplishment of targets, achieving short cycle times, and resulting in high-quality internal processes as a key feature of this strategy. From this specific perspective, the purpose of BSC is to understand how to increase efficiency and minimize cycle time for the related internal processes.

Based on the perception of managers of the results of this paper show that out of the 10 items of internal business perspective, satisfy customer needs have perceived as the top priority measure of internal business process perspective in Nepalese banks. It indicates a better internal business. Likewise, distribution reach and process delivery aspects of the internal process perspective have also got more preferences as per the perceptions of the managers. However, some other aspects such as service cycle duration, a sufficient number of training hours, and a comprehensive innovation process seem to be less preferred.

In the case of comparison among three types of banks, the results show that all types of banks have found less service cycle duration. In terms of distribution reach, it is found that private banks and joint venture banks have agreed that they have a wide range of distribution reach that that of state owned banks. In the case of new products/services, the joint venture banks have the practice of introducing new products/ services more than the private banks and state owned banks. However, state owned banks reasonably 
provide a sufficient number of training hours compared to the trend of private banks and joint venture banks.

In terms of identification of customer needs, process delivery, and comprehensive innovation process, all types of banks are convinced that their bank identifies customer needs frequently. In the case of the operation process, it is found that the joint venture banks have applied smooth and systematic operation processes more than the private bank and state owned banks. Likewise, in the case of post-sales service banks especially from the joint venture and private groups have offered more post-sale service than that of the state owned banks. However, in the case of satisfying customer needs, all types of banks can satisfy their customer needs. The overall results show that the internal business process as per the response is satisfactory.

\section{References}

Alshammari, A. M. (2011). The evaluation of the impact of using balanced scorecard on strategic performance in small and medium enterprises. Galway-Mayo Institute of Technology, Ireland.

Anand, M., Sahay, B. S., \& Saha, S. (2005). Balanced scorecard in Indian companies. Vikalpa, 30 (2), 11-25.

Hasan, R.U., \& Chyi, T.M (2017). Practical application of Balanced Scorecard - A literature review. Journal of Strategy and Performance Management, 5(3), 87103.

Hegazy, M., Hegazy, K, \& Eldeeb, M. (2020). The balanced scorecard: Measures that drive performance evaluation in auditing firms. Journal of Accounting, Auditing \& Finance. https://doi.org/10.1177/0148558X20962915

Kaplan, R. S., \& Norton, D. P. (2006) How to implement a new strategy without disrupting your organization. Harvard Business Review, 100-109.

Kaplan, R. S., \& Norton, D. P. (1992). The balanced scorecard: Measures that drive performance. Harvard Business Review, 70(1), 71-79.

Kaplan, R. S., \& Norton, D. P. (2001). Transforming the balanced scorecard from performance measurement to strategic management: Part I. Accounting Horizons, 15(1), 87-104.

Kaplan, R. S., \& Norton, D. P. (2004). The strategy map: guide to aligning intangible assets. Strategy \& Leadership, 32(5), 10-17.

Kaplan, R. S., \& Norton, D. P. (2005). The office of strategy management. Harvard Business Review, 72-80.

Mendoza, C., \& Zrihen, R. (2001). Measuring Up. Financial Management, April, 26-29. 
Olson, E., \& Slater, S. (2002). The balanced scorecard, competitive strategy, and performance. Business Horizon, 11-16.

Parajuli, D. (2017). Performance evaluation of Nepalese commercial banks based on balance scorecard. Unpublished Ph.D. Thesis, Faculty of Management, Tribhuvan University, Nepal.

Sharma, P. (2003). Stakeholders mapping technique: Towards developing of family firms typology. Laurier, 1, 1-5.

Szóka, K. (2012). The significance of the Balanced Scorecard financial perspective Presented through the example of the AMOENA Medical Devices Trade and Provider Ltd. Journal of International Studies, 5(1), 84-94.

Waluyo, M. et al., (2015). Analysis of balance scorecards model performance and perspective strategy synergized by SEM. MATEC Web of Conferences, 58, 02003, $1-8$. 